\title{
Ideational Power and Pathways to Legitimation in the Euro Crisis
}

\author{
Carstensen, Martin B.; Schmidt, Vivien A.
}

Document Version

Accepted author manuscript

Published in:

Review of International Political Economy

DOI:

10.1080/09692290.2018.1512892

Publication date:

2018

License

Unspecified

Citation for published version (APA):

Carstensen, M. B., \& Schmidt, V. A. (2018). Ideational Power and Pathways to Legitimation in the Euro Crisis. Review of International Political Economy, 25(6), 753-778. https://doi.org/10.1080/09692290.2018.1512892

Link to publication in CBS Research Portal

\section{General rights}

Copyright and moral rights for the publications made accessible in the public portal are retained by the authors and/or other copyright owners and it is a condition of accessing publications that users recognise and abide by the legal requirements associated with these rights.

Take down policy

If you believe that this document breaches copyright please contact us (research.lib@cbs.dk) providing details, and we will remove access to the work immediately and investigate your claim. 


\title{
Ideational Power and Pathways to Legitimation in the Euro Crisis
}

\author{
Martin B. Carstensen and Vivien A. Schmidt
}

Journal article (Accepted manuscript*)

\section{Please cite this article as:}

Carstensen, M. B., \& Schmidt, V. A. (2018). Ideational Power and Pathways to Legitimation in the Euro Crisis. Review of International Political Economy, 256), 753-778. https://doi.org/10.1080/09692290.2018.1512892

This is an Accepted Manuscript of an article published by Taylor \& Francis in Review of International Political Economy on 30 Jan २०19, available online:

DOI: http://www.tandfonline.com/10.1080/09692290.2018.1512892

* This version of the article has been accepted for publication and undergone full peer review but has not been through the copyediting, typesetting, pagination and proofreading process, which may lead to differences between this version and the publisher's final version AKA Version of Record.

Uploaded to CBS Research Portal: December २०२० 


\title{
Ideational power and pathways to legitimation in the euro crisis*
}

\author{
Martin B. Carstensen \\ Department of Business and Politics \\ Copenhagen Business School \\ Vivien A. Schmidt \\ The Frederick S. Pardee School of Global Studies \\ Boston University
}

Forthcoming in Review of International Political Economy

\begin{abstract}
How have European Union institutional actors sought to build, defend or undermine the legitimacy of crisis management during the euro crisis? Scholars have tended to investigate the euro crisis from either a pragmatic and prescriptive perspective - asking which reforms are necessary to build legitimacy in the governance structure of the Eurozone - or an analytical perspective focused on the power wielding of actors useful for understanding what actors have done and why they have been influential or not. The paper argues that rather than bifurcating the issues of legitimacy and power politics, much may be gained by investigating the relationship between legitimacy and power. Specifically, the paper employs the concept of ideational power to analyze the strategies through which actors have sought to defend their claims to three constitutive dimensions of legitimacy - input, output and throughput legitimacy - and proposes a matrix of nine pathways to legitimation that played into processes of legitimacy battles in the Eurozone crisis.
\end{abstract}

Key words: Power - legitimacy - ideas - discourse - euro crisis - European Union

\section{Introduction}

Doubts about the legitimacy of the European Union (EU) and of Eurozone governance have played a central role in academic and public debates about crisis management and the future of the Union (e.g., Champeau et al. 2015; Cramme and Hobolt 2015; Scharpf 2013, 2014a; Schmidt 2015, 2016; Tsoukalis 2016). Issues related to the legitimacy of the EU have of course been raised and debated for decades. But while earlier scholarly debates were divided on whether or not the EU suffered from a lack of legitimacy - whether in terms of citizen participation and elite responsiveness, institutional accountability and transparency, policy effectiveness and performance, or political deliberation in a transnational public sphere (e.g. Majone 1998; Scharpf 1999; Moravcsik 2002; Follesdal 2006; Hix 2006; Schmidt 2006; Risse 2010)—they are no longer. Something resembling a consensus has emerged that the European Union is today faced with the pressing problem of legitimating its increasing impact on the national level. This judgment follows in the wake of the euro crisis, the refugee crisis, and the more recent populist surge, making the issue of the EU's waning democratic legitimacy a key political problem.

Rather than focusing on pragmatic issues, such as for example how the European Union may be reformed in response to such problems (see e.g. Matthijs 2017a; Scharpf 2013, 2016; Tsoukalis 2016), this conceptual paper investigates how European Union institutional actors have sought

* This research was funded by the European Commission Horizon 2020 project "European Legitimacy in Governing through Hard Times" (\#649456-ENLIGHTEN). 
to build legitimacy during the euro crisis. More specifically, it analyses the strategies that institutional actors have pursued in the euro crisis to build and sustain their legitimacy, and argues that we may in important ways account for such actions as efforts to build legitimacy through the exercise of ideational power. From this vantage point, we may appreciate not only that power needs legitimacy to be effective in a longer term perspective (Weber 1978, Beetham 1991) but also that the processes through which legitimacy is established and defended are in turn critically connected to the exercise of ideational power in struggles between contending views of the world. With regard to legitimacy, the paper employs recently developed concepts in the literature centered on the normative mechanisms through which legitimacy may be established, including input, output and throughput legitimacy (Scharpf 1999, Schmidt 2013). Approaching legitimacy from a constructivist perspective (Reus-Smit 2007, Seabrooke 2006) and the analysis of ideas and power from a discursive institutionalist approach (Schmidt 2008, 2017; Carstensen and Schmidt 2016) , this paper is thus concerned less with considerations of policy or institutions and more with what EU institutional actors have discussed, contested, and done in terms of legitimacy during hard times. Using the case of the Eurozone crisis, the paper will illustrate the many different ways in which EU agents have deployed the power of ideas to lay claim to legitimacy.

Although the paper's primary empirical focus is the management of the euro crisis, it offers conceptual insights more broadly relevant for constructivist international political economy. First, while scholars have long recognized the centrality of legitimacy for stabilizing institutional orders (see Widmaier et al. 2007), less has been done in terms of differentiating between different kinds of legitimacy, and how actors' effort to balance between competing notions of legitimacy may over time come to produce significant institutional change. Here we leverage insights from a rich literature in EU studies on input, output and throughput legitimacy to theorize how strategic agency can build, maintain or challenge the legitimacy of an institutional setup. Second, the paper highlights the dynamism of legitimacy struggles and how the contingency they breed feeds into processes of institutional change. Specifically, the paper provides a framework for understanding both why certain agents' ideas about legitimacy become dominant but also how such notions may be challenged and eventually overturned by competing coalitions of actors, be they elite or non-elite. We thus contend that conceptually foregrounding legitimacy in the analysis of the struggle of political and economic ideas offers a clearer view of processes through which ideas gain or lose their power. Finally, it is well worth noting that the nine pathways to legitimacy developed in this paper should be viewed as a framework of analysis rather than a theory of power and legitimacy. In this view, the key contribution of the paper is to provide a view of legitimacy struggles relevant for understanding different parts of the policymaking process, where scholars may choose to focus on how one kind of legitimacy is impacted by ideational power, or alternatively how one dimension of ideational power interacts with the three kinds of legitimacy. In other words, the usefulness of the framework does not rely on it being employed in its entirety, but may rather work as a conceptual vehicle for relating ideational power to different kinds of legitimacy struggles.

The paper is structured as follows. The next section discusses the specific legitimacy problems related to the institutional setup of the EU, and defines legitimacy following the distinction between input, output and throughput legitimacy. Section three presents a conceptualization of ideational power, while the fourth section combines the two dimensions of legitimacy and 
ideational power, and discusses the various strategies that institutional actors have pursued to build and sustain legitimacy in the euro crisis. The fifth and final section concludes.

\section{Power and Legitimacy in the EU context}

In the Eurozone crisis, power has been at the center of political scientists' considerations of policy responses. These include the coercive power of Germany with Northern European allies and Brussels institutions to impose their preferences on Southern European debtor countries through hard bargaining games (Schimmelfennig 2015, Tsebelis 2015) and the reinforcement of stringent EU economic governance rules (Hall 2016, Scharpf 2014a); the structural power of political economic arrangements, including pressures brought on from the crisis of democratic capitalism (Streeck 2014) or by the transnational European capitalist class (Apeldoorn 2013); and the institutional power of path-dependent rules (Verdun 2015, Salines et al. 2012) from which EU actors have continuously 'failed forward' (Jones et al. 2015). Ideational power is often left out, but plays an equally important role, for example in accounting for the German leadership's capacity to frame the crisis as a problem of fiscal profligacy with austerity and structural reform as the only solution (Matthijs and McNamara 2015), or the primacy of ordoliberal ideas in the stability policies (Blyth 2013, Helgadottir 2016, Schäfer 2016).

Paying attention to ideational power is useful not only as a way of probing the many different ways in which power has been exercised in the Eurozone crisis (see Carstensen and Schmidt, 2018). It also provides a link to another area of concern, that of legitimacy. The concepts of power and legitimacy are intimately bound up with each other. Although the acceptance of authority may originate in motives like self-interest, habit or even submission to coercion, to be stable in the long run, the power related to authority is in need of legitimation (Weber 1978). Following Beetham (1991: 12-13), we may think of the legitimacy of relations of power in three interconnected ways, namely the legal validity of the exercise of power, the justifiability of the rules in relation to the beliefs and values shared by the dominant and subordinate in a society, and the evidence of consent on the part of subordinates derived from actions expressive of it. That is, when we assess the legitimacy of a particular approach to governance or to a specific set of policies, we are concerned not only with whether the actions taken under these systems are in accordance with relevant rules, but also how they are justified in terms of the beliefs, values and normative standards that people hold (Beetham 1991: 11; Sternberg 2015).

Although legitimacy cannot be reduced to ideas, it is clear that it involves normative ideas about what is appropriate and acceptable in political action and policy practices. In consequence, actors will participate in definitional struggles to shore up beliefs in the alignment between actions, rules and the normative expectations that underpin policies (Widmaier et al. 2007). Understanding the historical specificity of legitimacy, and more concretely the changing discursive landscapes of competing ideas about what constitutes legitimacy in the case of the EU (Sternberg 2013) thus demands that we investigate what particular ideas, discourses and norms form the basis for claims about legitimacy, and how actors succeed (or not) in making such claims (Seabrooke 2006; Schmidt 2013). 
Following Max Weber's definition, legitimacy depends on citizens' prior acceptance of a set of governing arrangements as morally authoritative, such that they will voluntarily comply with government acts even when these go against their own interests and desires (see e.g., Scharpf 1999; Cerutti 2008; Schmidt 2013). This kind of legitimacy, linked to acceptance of institutions as having moral authority, has traditionally been situated at the level of the nation-state, and linked to notions of national sovereignty and community. But slowly and incrementally over the course of the EU's integration process, as sovereignty became increasingly pooled (Keohane and Hoffmann 1991) and nation-states became 'member-states' (Bickerton 2012), this kind of legitimacy was also incrementally established (at least in principle) at the EU level in policy area after policy area and institution after institution by national governments, national courts, and by implication by European citizens. That said, deeper European integration-even prior to the Eurozone crisis-has taken its toll on member-states' national democracies, as more and more policies have moved up to the EU level for decision-making while politics remains national. What is more, the Eurozone crisis has greatly accelerated the pace of integration along with the intensity of questions regarding whether the $\mathrm{EU}$ is sufficiently legitimate let alone democratic. Importantly, even if citizens' use of the euro in their everyday practices suggests that they have tacitly accepted its authoritative legitimacy as a currency (McNamara 2015), they have increasingly politically contested the legitimacy of euro-related policies and processes.

There are many different theoretical approaches to democratic legitimacy. These generally run the gamut from normative theories that define the expected criteria a democratic political system would need to fulfill to be considered legitimate to empirical theories that evaluate the extent to which a given democratic political system is considered legitimate. The normative approaches tend to be deductive and often derived from philosophical principles concerned with the public good, political equality, justice, fairness, identity, public discourse, and deliberation (e.g. Beetham and Lord 1998, Bellamy and Weale 2015). Such approaches normally set up a range of criteria or standards of evaluation by which to assess public action. The empirical approaches tend to be more inductive and derived from pragmatic questions about such things as elite and mass perceptions of economic performance, political responsiveness, and administrative accountability as evidenced in opinion polls, voting, and public discourse (e.g., Gilley 2009; Schmitt and Thomassen 1999; Koopmans and Statham 2010; Hobolt 2015; van der Brug and De Vrees 2016). Such empirical investigations focus on citizens' beliefs about legitimacy and on community-based evaluations of public action as well as on the ways in which institutional authorities' actions are legitimated and contested in ways that shape such beliefs.

The approach to EU legitimacy presented in this paper combines the normative and the empirical by building on a set of concepts that are normative in their criteria for legitimacy but serve at the same time as useful categories for empirical investigation (see also Beetham 2013; Sternberg 2015). Normative considerations naturally infuse empirical investigations, since the two are impossible to disentangle, in particular because empirical perceptions are generally influenced by normative principles and standards about what ideally to expect. We thus take seriously the Weberian insight that legitimacy is rooted in beliefs, and follow Sternberg (2015) in emphasizing how legitimacy also depends on actors' ability to justify in terms of "beliefs, narratives, and conceptual language shared by, and among, dominants and subordinates" (p. 617). In this view, claims to legitimacy are essentially contested "as political actors are trying to claim, maintain or challenge the legitimacy of regional institutions" (Rittberger and Schroeder 2016: 581). Uncovering how beliefs about legitimacy develop through contestation thus 
requires a discursive investigation of the grounds or criteria on which actors base their claim to legitimacy (Beetham 2013: 20), and how actors seek to speak to different audiences that "may be concerned with different dimensions of legitimacy, and assign differential importance to them" (ibid.: 25). Introducing notions of contestation leads us to ask how (Weberian) legitimacy, as public consent to governing authority, is reinforced, or legitimated. And for legitimation, it is useful to consider how different kinds of governing activity can serve to support, or undermine, perceptions of governing authority.

\section{Legitimacy as input, output and throughput}

To make the overarching concept of legitimacy more tangible, we turn to current theorizing of legitimacy in the context of the European Union, which has long been focused on the different kinds of governing activity that serve to legitimate governing authority. With inspiration from systems theory (Easton 1965; Scharpf 1970), democratic legitimacy in the European Union has been theorized in terms of two major concepts: input legitimacy, focused on political representation and responsiveness, and output legitimacy, concerned with policy effectiveness and performance (Scharpf 1999, 2014a; see also Majone 1998; Bellamy 2010). More recently, the concept of throughput legitimacy, centered on the procedural quality of governance processes, has been developed to fill a gap in the theorization of legitimacy (Schmidt 2013).

Generally defined, output legitimacy depends on the extent to which policy choices provide for the common good, which is predicated on those policies' effectiveness in 'delivering the good(s)' in terms of policy results. In other words, output is a performance criterion for legitimacy, which expects responsible governance to generate policies that work well by producing good results with appropriate outcomes. Input legitimacy depends instead on the extent to which policy choices reflect 'the will of the people,' which is predicated on citizens' engagement in representative processes and government responsiveness to citizens' concerns and demands. Hannah Pitkin's classical definition of political representation puts it as: 'acting in the interest of the represented in a manner responsive to them' (Pitkin 1967: 209). It is thus a political criterion for legitimacy, which requires responsive governance focused on satisfying citizens' concerns as expressed in a common arena. Throughput legitimacy sits between the input and the output, in the 'black box' of governance, and depends on the quality of the policymaking processes (Schmidt 2013). The qualitative criteria for such processes include the efficacy of the policymaking, the accountability of those engaged in making the decisions, the transparency of the information, and the processes' inclusiveness and openness to consultation with interest groups and 'civil society'.

In brief, output is a performance criterion for legitimacy, which expects responsible governing for the people to generate effective policies with appropriate outcomes. Input is a political criterion for legitimacy, which requires responsive governing by and of the people focused on satisfying citizens' concerns as expressed in a common arena. And throughput is a procedural criterion for legitimacy, which demands efficacious governing with the people through processes that are accountable, transparent, inclusive and open to interest intermediation. In any national democracy, the system can be depicted as a flow from citizen input through procedural throughput in the 'black box' of governance to policy performance output, and back to citizen input through feedback mechanisms. 
It is well worth noting that input, output, and throughput legitimacy are not created equal. Input and output are often seen to involve trade-offs, where good policy performance may make up for a lack of citizen participation, or where the citizens' mandate for a given policy ensures its legitimacy, even if it produces poor results (e.g. Katz and Wessels 1999, Torres 2006). At the same time, however, the relationship between input and output legitimacy is also characterized by interdependence. We can see this not only with regard to the political representative's choice between being responsive (for input legitimacy) or responsible (for output legitimacy) but also in terms of citizens' ability to sanction governments that they deem to have failed to perform responsibly (output legitimacy) and/or in ways that meet their needs, fit with their values, and respond to their wishes, as expressed in the previous election cycle (input legitimacy). That is, good performance (output) does not guarantee legitimacy if citizens feel that the regime is not sufficiently responsive to their interests (McEvoy 2016). This interdependence between input and output legitimacy importantly puts the onus on actors to continuously (re)construct how their actions and policies speak to both input and output concerns (Sternberg 2015).

Things are more straight-forward in the case of throughput legitimacy, where there is no clear trade-off. Efficient procedures that are sufficiently inclusive and open while ensuring appropriate accountability and transparency mainly guarantee that citizen input moves through the system without impediment to the output results. But poor quality procedures that are seen as incompetent or corrupt, oppressive or overly secret can delegitimize both input, by appearing to skew the politics, and output, by seeming to taint the outcomes (Schmidt 2013). Throughput legitimacy has thus long been one of the central ways in which EU institutional players have sought to counter claims about the poverty of the EU's input legitimacy and to reinforce claims to its output legitimacy (Héritier 1999). In so doing, such actors have operated under the assumption that high quality throughput may serve as a kind of 'cordon sanitaire' for the EU, ensuring the trustworthiness of the processes and serving, thereby, as a kind of reinforcement or, better, reassurance, of the legitimacy of EU level output and attention to input. As already noted in the context of input and output legitimacy, the efficacy of this argument hinges not on the strength of the argument in and of itself, but rather on the capacity of actors to craft powerful narratives under specific institutional and political circumstances.

\section{Legitimacy in a multi-level setting}

The multi-level nature of the EU system further complicates questions of democracy and legitimacy for the EU and its member-states, since the legitimizing mechanisms of output, input, and throughput are largely divided between EU and national levels. Because the EU lacks the political legitimacy (input) of a directly elected government, supported by a 'demos' in which citizens share a sense of identity and common purpose (Weiler 1995), its legitimacy rests primarily on the effective performance of the policies (output) and the quality of the processes (throughput) at the EU level. In contrast, the national level is mainly focused on political (input) legitimacy, as the locus of national elections and the principal source of citizen identity.

In the early years, scholars thus assumed that the only legitimacy possible for the EU was 'output' legitimacy, based on good economic and social performance (Keohane and Hoffmann 1991; Haas 1958; Sandholtz and Stone Sweet 1998). Over time, however, came an increasing 
focus on the quality of the governance processes under the influence of neo-liberal economic philosophy, which favored technocratic throughput over popular input to produce optimal output (e.g. Majone 1996, 2001). As a result, throughput legitimacy often joined output legitimacy (or was even conjoined with it) under the assumption that this enhanced policy effectiveness (Schmidt 2013). Such a focus on policy and process has largely been seen as responsible for the depoliticization of EU policymaking, in which neo-liberal policies have been presented as technical and neutral, such that TINA, there is no alternative, and therefore no political debate necessary-or possible (Fawcett and Marsh 2014; Flinders and Wood 2014; Schmidt and Thatcher 2013).

However, over time the EU has become increasingly political, and with this input legitimacy has been a growing focus of concern. Even before the EU's multiple crises, analysts noted the growing importance of crosscutting cleavages at the national level between traditional political divisions based on adherence to right/left political parties and newer identity-related divisions based on xenophobic/ authoritarian/communitarian versus cosmopolitan/liberal values (Hooghe and Marks 2009, Kriesi et al. 2008). In recent years, however, the pace of nontraditional politicization has accelerated with each successive crisis, beginning with the Eurozone crisis. Such politicization has been most apparent at the national level, with the rise of the populist extremes in social movements, political parties, and even in government (Kriesi 2014; Hix and Hoyland 2015), most notably in the so-called 'illiberal democracies' of Hungary and Poland (Kelemen 2017). But it has also infected the EU level. In the Council, we see the growing influence of public opinion and electoral politics on member-state leaders' positions; in the European Parliament, the election of extremist parties.

While depoliticization may have long characterized EU level governance, politics-along with input legitimacy - has remained primarily at the national level. Despite the fact that EU level input legitimacy has often been ascribed to the Council via member-states' indirect representation of their citizens and to the EP through their direct elective representation of the citizens, these don't compare to national input legitimacy. The Council is not a representative arena and the EP is only marginally representative, given the high rate of voter abstention (see, e.g., Scharpf 1999; Hix 2008; Rittberger 2014). The problem for national input legitimacy and therefore democracy is that the EU has encroached more and more on national decisionmaking. And as more and more decisions moved up to the EU level, the national level became increasingly what Schmidt (2006) a decade ago termed 'politics without policy.'

\section{Legitimacy and ideational power}

While the tripartite distinction between input, output and throughput legitimacy is useful for distinguishing between the key elements of legitimacy, it has so far primarily been used to make judgments concerning the extent to which political systems heed basic democratic requirements of representation, performance and procedure (e.g. Scharpf 1999). One potentially fruitful way to apply these dimensions of legitimacy to the analysis of efforts to legitimize political action is by connecting them to the concept of ideational power. Doing so brings into view how legitimacy is not simply a condition that holds or not, nor is it a condition reached by proclamation. As argued by Seabrooke (2006: 23), studying legitimacy from a 
constructivist point of view encourages us to focus on contestation among elites as well as between elites and the larger population (see also Reus-Smit 2007). Taking this kind of constructivist perspective on elite and popular contestation enables us to connect processes of legitimation to the exercise of ideational power.

Such a perspective also helps us connect with what Beetham (1991: 64) calls "the self-fulfilling character of legitimate power", i.e. "the way in which systems of power themselves structure many of the beliefs, interests and conditions of consent that provide for their legitimation". That is, it helps underscore the point that although power needs to be legitimate to remain stable and effective, in the final instance it is the perception of legitimacy and the actions that indicate consent on the part of subordinates that matter for the stability and efficiency of a political system. Put differently, power requires legitimization, and efforts to legitimize are connected with the exercise of power. Moreover, as noted above, such efforts to legitimize are largely ideational and discursive, because agents use ideas to legitimize their actions through discursive contestation, as opposed to simply coercing people, structuring relations or instituting rules without discourse-which are actions that may serve their purposes but do not ensure legitimacy.

To differentiate between different forms of power, and how they mattered for EU institutional actors' contests over legitimacy during the euro crisis, we require as a starting point a general notion of power. Here we draw on the later Lukes' (2005: 65) definition of power as 'agents' abilities to bring about significant effects, specifically by furthering their own interests and/or affecting the interest of others, whether positively or negatively". Taking this definition of power as our starting point has a number of important implications. First, we focus on the capacity to promote or inhibit the interests of actors. In this perspective, power is not equal simply to causality, where power means having some kind of effect on the behaviour (broadly conceived) of others. Our definition of power is instead focused on those instances where the actions of A impact on the ability of B to get what B wants, whether positively or negatively. Second, power is conceived in agency terms. This means that when speaking of power we are referring to the capacities of (individual or collective) agents to affect the interests of other actors and not to the ways in which economic, political or ideational structures per se may affect the interests of actors. While such structures may serve as resources in or objects of agents' power relations, they are not at the centre of our definition of power, which involves agents with relative autonomy who could have acted differently had power not been exercised. In short, power implies that choices were made that impacted on the interests of agents (Lukes 1977).

It is also worth noting that although we develop our arguments from the starting point of an agency oriented approach to understanding relations of power, there is little doubt that structural forms of power too play an immensely important role in understanding processes of legitimation (see also Carstensen and Schmidt 2018). Notably, a particularly vibrant research agenda has formed around the argument that the structural power of finance has impacted heavily on crisis management and post-crisis reform trajectories (Culpepper and Reincke 2014, Culpepper 2015), a structural power crucially shored up by the dominance of ideas that serve to legitimize the financialized economies of the West (Woll 2014). In focusing on ideational power, and the different guises under which it may be employed to build legitimacy, our framework provides a view of the ways in which agents use their structural power in concrete struggles 
over legitimacy, or indeed how structural power may be significantly challenged as new conceptions of legitimacy come to the fore.

We define ideational power as the capacity of actors (whether individual or collective) to influence other actors' normative and cognitive beliefs through the use of ideational elements (Carstensen and Schmidt 2016). In this view, ideational power has certain distinguishing features. First, struggles for legitimacy take place among actors and groups seeking to push their preferred interpretation of legitimacy towards general acceptance among elites and the population at large. Second, ideational power is conceived as both a top-down and a bottom-up process, with discursive struggles taking place not only among elite actors at the top of the power hierarchy but also at the bottom by non-elite actors focused on getting their ideas across to the top as well as to the general public. Legitimacy, in other words, requires that actors defend their particular interpretation by persuading other actors of its justification (Seabrooke 2006).

With this in mind, we may identify three ways of theorizing about the power of ideas and discourse. These include persuasive power through ideas via discourse, coercive power over ideas and discourse, and structural or institutional power in ideas and discourse (for further discussion, see Carstensen and Schmidt 2016). Power through ideas consists of the capacity of actors to persuade other actors of the cognitive validity and/or normative value of their views of what they should think and do through the use of ideational elements. They tend to do this via discourses that serve to explain and/or legitimate their proposals and actions, whether in coordination with other policy actors (coordinative discourse) or in communication with the public (communicative discourse).

Power over ideas is the capacity of actors to control and dominate the meaning of ideas either directly, by imposing their ideas on others, or indirectly, whether through shaming opponents into conformity or by resisting alternative interpretations. This version of ideational power connects with more coercive forms of power, since here the beliefs of others are directly disregarded. In the context of the euro crisis, the most obvious example of ideational domination has been from the 'Brussels-Frankfurt consensus' (the ECB, the Commission, and Germany, including the Bundesbank) (Howarth and Rommerschild 2013). This was most notable in these actors' capacity to frame the crisis for all other EU actors and citizens, like it or not, as one of public debt rather than private, diagnose the crisis as behavioural, as resulting from the failure to follow the rules rather than from the structure of the euro, and therefore to prescribe remedies of austerity and structural reform that failed to resolve the crisis (Blyth 2013, Matthijs and McNamara 2015). Alternatively, power over ideas can also come from less powerful actors, by shaming their more powerful opponents into agreement. One example of this is how the main parties in the European Parliament successfully pushed the idea of the Spitzenkandidat, in which the leader of the winning majority in the elections would have to be named president of the Commission, despite major resistance from powerful Council members (notably Germany and the UK).

Power in ideas focuses on the authority certain ideas enjoy in structuring thought at the expense of other ideas. This can be seen as structural or institutional. Structural power in ideas results from agents having established hegemony over the production of subject positions, whereas institutional power in ideas is a consequence of institutions imposing constraints on what ideas agents may take into consideration. While the other forms of ideational power 
generally concentrate on the interactions between ideational agents, power in ideas mostly concerns the deeper-level ideational and institutional structures that actors draw upon and relate their ideas to in order for them to gain recognition from elites and the mass public (Carstensen and Schmidt 2016: 329-331). This certainly speaks to the ways in which German ordoliberal ideas of the 'stability culture' were institutionally embedded in the ECB's Charter as well as how EU intergovernmental, supranational, and parliamentary actors all found it easiest to agree to reinforce the rules and numbers in the Eurozone in the heat of the crisis. It is also important to note that although these three forms of ideational power are analytically distinct, in real life they may be more difficult to separate. This is because agents may use all three simultaneously to reinforce a particular perspective on legitimacy, or they may cycle from one to the next, say, with the structural or institutional power in ideas challenged by agents wielding persuasive power through ideas or coercive power over ideas, which then ultimately produces a new structural or institutional power in ideas.

Finally, although the examples of legitimacy struggles in the euro crisis presented in section four mainly focus on the 'noisy' politics of crisis management between EU institutional actors during the fast-burning part of the crisis (Seabrooke and Tsingou 2018), this should not be taken to imply that legitimation does not matter for the 'quiet politics' (Culpepper 2011) that has characterized a significant part of post-crisis financial and economic reform (Braun et al. 2018). Indeed, the framework of this paper also applies to processes of legitimation that take place outside the public eye. Such legitimacy struggles require less in terms of developing an effective communicative discourse and instead puts the onus on elite actors to convince each other, a process through which the expertise and professional know-how offered by industry representatives often carries the day (Seabrooke 2014, Pagliarai and Young 2016). One pertinent example of the power of expertise is presented by Braun and Hübner (2018) who demonstrate how the Commission together with private actors, notably financial sector lobbyists, played a central role in providing the theoretical and practical firepower for the construction of the Capital Market Union. Without a clear blueprint for reform, these actors depended on their capacity for 'intra-elite persuasion' (Blyth 2007) that in large part hinged on claims to knowledge and expertise (Braun and Hübner 2018). But even in this relatively 'quiet' policy process (see Epstein and Rhodes 2018), the Commission was hard at work developing a communicative discourse legitimizing the Capital Market Union as helping medium-sized enterprises, while in actual policy it sought to build stronger capital markets as a source of funding for large banks (Engelen and Glasmacher 2018). Distinguishing between the three dimensions of ideational power, and how they each relate to legitimacy struggles, thus serves to highlight how legitimation occurs both between elite and public and through more 'quiet' intraelite relations. It also provides a view of the potential disruptions caused by the challenge of mitigating between the competing legitimacy concerns of multiple audiences.

\section{Nine pathways to legitimacy in the euro crisis}

Combining the three dimensions of legitimacy and ideational power, respectively, generates a total of nine strategies actors may pursue in legitimizing their actions or policies and in defending their particular understanding of what is legitimate against competing conceptions. These are outlined in Table 1. The basic idea of the table is that actors seek to establish or sustain their legitimacy, or the legitimacy of the institution they represent, through the exercise 
of ideational power. In this perspective, legitimacy is the overall goal of actors - a goal that potentially combines with other goals like gaining resources or institutional position - and ideational power is the means through which this goal is pursued.

The focus on ideational power is not to deny that non-ideational factors also matter significantly in struggles over legitimacy. There can be no doubt, as we will see below, that various kinds of non-ideational resources, including access to institutional position or the harnessing of economic resources, matter crucially for the capacity of agents to effectively legitimize actions, policies or ideas. As recently argued by Matthijs and Blyth (2017: 3), "social learning about what to do is dependent upon who is institutionally authorized to learn, their ability to make policy, and their power to define what actually counts as an anomaly and what does not." Following this line of thinking, we focus here on the ideational and discursive dynamics of legitimation, and follow how they are leveraged with material and institutional resources that serve to reinforce any such legitimation.

Table 1: Ideational power and legitimacy: Nine pathways to legitimacy

\begin{tabular}{|l|l|l|l|}
\hline & $\begin{array}{l}\text { Power through ideas } \\
\text { Capacity of actors to } \\
\text { persuade other actors } \\
\text { to accept and adopt } \\
\text { their views through use } \\
\text { of ideational elements }\end{array}$ & $\begin{array}{l}\text { Power over ideas } \\
\text { Imposition of ideas and } \\
\text { power to resist } \\
\text { inclusion of alternative } \\
\text { ideas into policymaking }\end{array}$ & $\begin{array}{l}\text { Power in ideas } \\
\text { Certain ideas enjoy } \\
\text { authority in structuring } \\
\text { thought or } \\
\text { institutionalizing certain } \\
\text { ideas at expense of } \\
\text { others }\end{array}$ \\
\hline $\begin{array}{l}\text { Output legitimacy } \\
\text { policy outcomes for the } \\
\text { people }\end{array}$ & $\begin{array}{l}\text { Persuading actors about } \\
\text { the superiority of } \\
\text { certain policies and } \\
\text { their beneficial } \\
\text { outcomes for the people }\end{array}$ & $\begin{array}{l}\text { Imposing certain policy } \\
\text { ideas, programs, and } \\
\text { philosophies while } \\
\text { disregarding and } \\
\text { disallowing alternatives }\end{array}$ & $\begin{array}{l}\text { Institutionalization and } \\
\text { hegemony of certain } \\
\text { policy approaches, } \\
\text { programs, and } \\
\text { philosophies at the } \\
\text { expense of others }\end{array}$ \\
\hline $\begin{array}{l}\text { Input legitimacy } \\
\text { citizen concerns as a } \\
\text { result of participation } \\
\text { by and of the people }\end{array}$ & $\begin{array}{l}\text { Persuading actors about } \\
\text { the EU's political } \\
\text { responsiveness to } \\
\text { citizen needs and } \\
\text { demands }\end{array}$ & $\begin{array}{l}\text { Imposing certain EU } \\
\text { and/or national ideas } \\
\text { about the EU's political } \\
\text { responsiveness to } \\
\text { citizen needs and } \\
\text { demands }\end{array}$ & $\begin{array}{l}\text { Institutionalization and } \\
\text { hegemony of certain } \\
\text { ideas about EU political } \\
\text { responsiveness to } \\
\text { citizen needs and } \\
\text { demands }\end{array}$ \\
\hline $\begin{array}{l}\text { Throughput } \\
\text { legitimacy } \\
\text { Quality of EU } \\
\text { governance processes } \\
\text { in terms of efficacy, } \\
\text { accountability, } \\
\text { transparency, } \\
\text { inclusiveness and } \\
\text { consultation with the } \\
\text { people }\end{array}$ & $\begin{array}{l}\text { Persuading actors that } \\
\text { procedural rules of } \\
\text { accountability, } \\
\text { transparency, } \\
\text { inclusiveness and } \\
\text { openness have been } \\
\text { followed with efficacy }\end{array}$ & $\begin{array}{l}\text { Imposing certain } \\
\text { conceptions of efficacy, } \\
\text { accountability, } \\
\text { transparency, } \\
\text { inclusiveness and } \\
\text { openness while keeping } \\
\text { alternatives off the } \\
\text { agenda }\end{array}$ & $\begin{array}{l}\text { Institutionalization and } \\
\text { hegemony of certain } \\
\text { approaches to efficacy, } \\
\text { accountability, } \\
\text { transparency, } \\
\text { inclusiveness and } \\
\text { openness }\end{array}$ \\
\hline
\end{tabular}


Note: Definitions for three dimensions of ideational power are drawn from Carstensen and Schmidt (2016). Definitions of three dimensions of legitimacy are taken from Schmidt (2013)

\section{Input legitimacy and ideational power}

When input legitimacy-defined as the EU's responsiveness to citizen concerns resulting from participation by and of the people-combines with ideational power, there are three different ways to map the pathways to legitimacy. In the case of power through ideas, meaning the capacity of actors to persuade other actors to accept and adopt their views through the use of ideational elements, input legitimacy is promoted by EU institutional actors who seek to persuade citizens or other EU institutional actors of the EU's political responsiveness to citizen needs and demands (or the lack thereof). In the case of power over ideas, meaning the imposition of certain ideas and/or the power to resist the inclusion of alternative ideas into the policymaking arena, input legitimacy is established by EU institutional actors imposing certain $\mathrm{EU}$ and/or national ideas about the EU's political responsiveness to citizen needs and demands. As for power in ideas, meaning when certain ideas enjoy authority in structuring thought or institutionalizing certain ideas at the expense of other ideas, input legitimacy results from the institutionalization and hegemony of certain ideas about EU political responsiveness to citizen needs and demands.

In the context of the euro crisis, it is important to note that EU institutional actors - whether we speak of the Council, the Commission or the European Central Bank -never were in a strong position to defend the input legitimacy of their actions. This follows from the very structure of the European Union, as discussed above, in which input legitimacy has mainly been located at the national level. For a very long time, however, this did not seem highly problematic, given the assumed trade-off between input and output legitimacy. Although discourses critical of output-focused notions of EU legitimacy have been voiced throughout the existence of the EU (Sternberg 2015), the dominant conception was long that so long as the EU delivered in terms of output legitimacy, input legitimacy was not at issue for citizens, at least as judged by their 'permissive consensus' (Lindberg and Sheingold 1970). But once a 'constraining consensus' developed in the 2000s (Hooghe and Marks 2009), it became increasingly clear that questions of input legitimacy could no longer be ignored. It was not until the euro crisis, however, that the EU's 'democratic' (input) legitimacy came to be seen as seriously at risk (Scharpf 2013; Schmidt 2013, 2016; Tsoukalis 2016; Curtin and Crum 2015; Cramme and Hobolt 2015). That is, in the language of this paper, the structuring power in ideas that follows from the institutionalization of certain ideas about the EUs input legitimacy -that a lack of (input) representation by the people could legitimately be compensated by good (output) policy results for the people - has come into question. As we shall see, this has pushed institutional actors to make greater claims to input legitimacy.

One of the claims to input legitimacy comes from the member-state leaders in the Council, who maintain that the EU's representation of and responsiveness to citizens' political demands and concerns is institutionally based on their indirect representation of their citizens in the Council. During the Eurozone crisis, member-state leaders actively defended the legitimacy of their 'executive intergovernmentalism', in which the member-states played the central role in crisis management via Council meetings and Eurozone summits, by citing their indirect election to the 
Council (Fabbrini 2013; Wessels and Rozenberg, 2013). In this view, the Council was the most representative forum, and the member states the most legitimate to legislate for all EU citizens-as President Sarkozy seemed to insist at the height of the Eurozone crisis when he defined a more democratic Europe as "a Europe in which its political leaders decide" and as Chancellor Merkel appeared to assume when she explicitly commended the new 'Union Method'. Another notable discursive strategy employed by Merkel to legitimize the central role of the Council in crisis management started taking shape in 2011. Revolving around the notion of Europäischen Innenpolitik (European domestic politics) it responded to growing criticism about a ne-nationalisation in Europe, which was increasingly directed at a perceived inward looking and self-serving reflex of Germany as a leader of crisis management. Merkel's narrative suggested instead that the Europeanisation of the domestic served to strengthen European democracy through the channels of electoral democracy and increased awareness of political developments beyond voters' own national setting (Sternberg et al. 2018: 102-103).

Not withstanding the vibrancy of European debates during the euro crisis, power, in its coercive, institutional and ideational variants, was clearly at play. With member states taking the lead in crisis management, and highly solvent 'creditor' countries pitted against de facto insolvent 'debtor' countries, it comes as little surprise that "government preferences in the Euro crisis have tended to reflect 'national interests' rooted in the structural financial positions of the Eurozone member states" (Schimmelfennig 2014: 328). Assuming that the Council serves as a representative forum thus fails to deal with the fact that during the Eurozone crisis, it acted initially more as a bargaining arena in which one member-state (Germany) exercised the greatest influence. Although academic scholarship on the Council has suggested that the deliberative mode prevails over hard bargaining even where qualified majority voting occurs because of the focus on consensus (e.g. Bickerton 2012), in the Eurozone crisis deliberation has occurred in the shadow of Germany (Schmidt 2015). In the months leading up to the May 2010 bailout of Greece, Germany, as the strongest economically and the most opposed to taking a decision, ensured that no decision could be taken, given the unanimity rule, until Chancellor Merkel finally agreed in order to "save the euro." The result has been that input-oriented policy choices at the national level have been disabled, putting pressure on EU citizens' historical 'benign neglect' of the lack of input legitimacy in the EU - a problem only exacerbated by economic governance reforms, the acceptance of which depended on output-oriented and uncertain promises of recovery, growth and long-term sustainability (Scharpf 2014b).

Even if actors were able to legitimate their agreement to impose legally binding austerity measures for everyone, delegating to their agent (i.e., the Commission) the discretionary authority to implement such rules was an easy object for criticism given the necessarily ad hoc nature of the specific application of those rules to any given country. So even though arguments have been made that the most input legitimate approach to managing the euro crisis is in placing primary authority in the Council, it is at the same time clear that power between Member States has been allocated in a highly uneven way, and that the primary channel of legitimation runs between the most powerful Council member states and their national constituents, especially given the growing influence of public opinion and electoral politics on member-state leaders' positions. Part of the approach has in turn involved shielding Eurozone integration from the impact of politicization by "avoiding and constraining referendums on institutional reform and by delegating competencies to supranational organizations" (Schimellfennig 2014: 323), further limiting parliamentary authority in member states (Auel 
and Höing 2014). In sum, backed by their economic resources, the creditor countries have been able to dominate the understanding of input legitimacy at the expense of competing notions espoused by economically weaker 'debtor' countries - and thus have exercised power over ideas concerning input legitimacy.

It is well worth noting, though, that such power over ideas has not been without its challenges. Notably, the EP has been particularly active in deploying power through ideas to persuade other EU institutional actors as to the input legitimacy of increasing its competencies, mainly with reference to its own electoral status as the only directly elected EU body (Hix and Hoyland 2013). That said, at the height of the Eurozone crisis, the EP did consent to the establishment of discretionary authority without EP oversight (Scharpf 2014b), particularly for the Commission in the European Semester exercise and for institutions established outside the treaties (notably the European Stability Mechanism and the Fiscal Compact). But this could itself be seen as an instance of the persuasive power through ideas of other EU institutional actors, to convince MEPs that such discretionary authority was the best response to the crisis at that moment.

In many domains, however, the EP was able to gradually expand its powers both formally and informally by using well-established parliamentary strategies, such as normative pressure and shaming tactics, to push a recalcitrant Council to do its bidding (Héritier et al. 2016; Hix and Hoyland 2013). The EP has been particularly successful in establishing the parliamentary accountability of executive action in relation to the adoption of legislative packages to reform the stability and growth pact, introduce macroeconomic surveillance procedures (Six-Pack) and to improve the co-ordination of national budgetary processes in the Eurozone (Two-Pack) (Rittberger 2014). Similarly, Rittberger (2014: 1180) argues that the establishment of a Banking Union was another example of the EP's ability to extract institutional concessions from the Commission and the Member states, since "Contrary to the Commission's initial proposal, the EP succeeded not only in strengthening its scrutiny powers vis-à-vis the supervisory board, it also obtained the right to formally approve (and dismiss) the chair and vice-chair of the SSM." The EP also managed to stage a major coup against the European Council, launching a system of Spitzenkandidaten during the European elections in May 2014, in which Jean-Claude Juncker as the candidate to lead the Commission of the European People's Party (EPP) was forced de facto on Europe's heads of state and government in June 2014, despite UK Prime Minister David Cameron's desperate efforts to reverse the process and stop Juncker in his tracks (Matthijs and Blyth 2015: 259). In sum, employing its claim to representation of the people, the EP was able to exert its persuasive power through ideas about the necessity of its own empowerment in order to increase input legitimacy in crisis management and Eurozone governance reform more generally.

\section{Output legitimacy and ideational power}

When ideational power is paired with output legitimacy, defined as the effectiveness of the EU's policy outcomes for the people, we again find three pathways to legitimacy. In the case of power through ideas, output legitimacy involves seeking to persuade actors of the superiority of certain policies and their beneficial outcomes for the people. With regard to power over ideas, output legitimacy involves imposing certain policy ideas, programs, and philosophies while disregarding and disallowing alternatives, often insisting that 'there is no alternative'. As for 
power in ideas, output legitimacy concerns the institutionalization and hegemony of certain policy approaches, programs, and philosophies at the expense of others. In the context of the euro crisis, the interaction between ideational power and output legitimacy is seen most clearly in EU institutional actors' efforts to bolster beliefs that following ordo- and neoliberal policy prescriptions offered the only way to a return to growth. These beliefs dominated the meaning of what constitutes policy success and disregarded alternative reform ideas.

Above we saw that although EU institutional actors made claims to input legitimacy, the particular structure of the EU - with most input legitimacy channeled through the national level - has historically, and more specifically in the euro crisis, made output legitimacy the most important way in which power has been sought turned into authority. Here too EU institutional actors were hard pressed to deliver, and the interaction between ideas and other forms of power played a decisive role in producing this situation. As is well known, the construction of EMU was based on the expectation that convergence through monetary integration would over time produce the political will necessary to build fiscal and economic integration (see Matthijs and Blyth 2015). Each member-state had compelling reasons to join, but very different ideas about what EMU would be and do, why it was necessary and appropriate to join, and how much sovereignty and control could or should be ceded to any new Eurozone governance (see Jabko 2015). Without any political agreement forthcoming on fiscal integration at the outset, Eurozone members instead signed up to the Stability and Growth Pact (SGP), which required a budget deficit of no more than 3 per cent of GDP, a public debt of 60 per cent of GDP, and an inflation rate of no more than 2 percentage points higher than the lowest rate among memberstates, and in any case at or below 3 percent. With the SGP, the EU in essence institutionalized the Brussels-Frankfurt consensus of ordo-liberal ideas about legitimate output goals for Eurozone economic policy. This was based on three basic tenets: stable money, to be guaranteed by the ECB's role in fighting inflation and ensuring price stability; sound finances, to be assured by the member-states, which were to eschew 'excessive' deficits and debt; and efficient local labor markets, to be carried out by the member-states, with each country responsible for making its own labor markets and welfare state 'competitive' in whichever way it could (Jones 2013).

That certain output goals at the outset enjoyed institutionalized power in ideas mattered for how crisis management was crafted and specifically which ideas gained a hearing among the most powerful EU institutional actors and which alternatives were disregarded and disallowed. Following a short-lived Keynesian moment in 2009, EU institutional actors' main responses to the euro crisis involved setting up loan guarantee mechanisms to shield countries under pressure from the markets, underpinned by intergovernmental agreements (inside or outside the treaties) plus legislative acts that served to reinforce the governance rules first set by the Maastricht Treaty and the SGP. Although many policy solutions to the crisis were proposed-for example, Eurobonds to mutualize debt, a "European Debt Agency" to issue bonds for countries in trouble, a European Monetary Fund to rescue countries in trouble-Eurozone governments did the minimum. They agreed to the Greek loan bailout and a temporary loan guarantee fund, the European Financial Stability Facility (EFSF), for countries in danger of contagion from the crisis in May 2010; a more permanent European Stability Mechanism (ESM), first discussed in 2010, which came into operation in 2013; and a Banking Union, set up during 2013. The principles underlying these agreements were largely based on the 'Brussels-Frankfurt consensus'. EU institutional actors' rationale for instituting the increasingly strict rules-based 
governance followed from their interpretation of the crisis from the very beginning as a failure to follow the rules of the SGP, which had consecrated the Brussels-Frankfurt consensus on Eurozone economic policy (Matthijs and Blyth 2017, Scharpf 2014b).

The distributive impact of the power of the 'Brussels-Frankfurt consensus' was felt very differently across the core and periphery of the euro zone (Copelovitch et al. 2016, Matthijs 2017b, Schmidt 2015), with little effect on output legitimacy in the core countries, whereas the long and painful recessions of periphery countries has severely hurt the output legitimacy of euro zone crisis management (Braun and Hübner 2018). It thus comes as little surprise that although the institutionalized power in ideas of certain notions of legitimate output framed the crisis response, these ideas were challenged as the crisis developed. Ordo- and neoliberal ideas remained resilient in the initial stages of the crisis, but an unspoken recognition started to built that the rules generated by such ideas were not working, and, as such, constituted a threat to output legitimacy. That is, only as the economic output results continued to deteriorate, with unemployment skyrocketing and growth plummeting, did calls for changes in policies come to be voiced. This is when EU actors' persuasive power through ideas came to the fore, as memberstate leaders in the Council first deliberated about whether to promote growth, then about whether to ease the rules, which in turn encouraged the Commission to increase its own flexibility in the application of the rules.

Growth became a matter of debate among EU leaders beginning in late 2011, when newly appointed technocratic Italian Prime Minister Mario Monti started talking about the need to focus on growth, and was quickly followed in 2012 by the campaign discourse of French Socialist presidential candidate and then President François Hollande. This had the advantage of revealing that the policies presented as apolitical technocratic solutions that would produce optimum output performance were actually political, and conservative, and that politics therefore also exists at the EU level. But although growth entered the discourse, it did nothing to change the ordo- and neoliberal cast of the policies, which were equally implemented by Monti and Hollande. A similar outcome occurred when flexibility in the application of the rules became the new focus of debate in 2014, with the arrival of a new Italian Prime Minister-Matteo Renzi-supported by Hollande. Merkel's response, in a speech to the Bundestag in June 2014, was that there was no need to change the rules since the Stability and Growth Pact already contained all the necessary flexibility.

Although there was no formal change in rules, the debates first over growth and then flexibility reinforced the Commission's decision to ease its application of the rules. Increasingly concerned about the loss of output legitimacy due to failing performance, the Commission more and more frequently granted derogations and exceptions to the rules, despite criticism from some Northern European member-states (Schmidt 2016). In essence, the Commission used its power over ideas about how to implement the European Semester to incrementally challenge what had in the initial stages of the crisis been the overwhelming power over ideas of the most influential EU institutional actors, who saw harsh austerity and structural reform as the only way to deliver the most effective outcomes for the people. The Commission President Juncker's push for investment, with the creation of the European Fund for Strategic Investment, could instead be seen an instance of the Commission's power through ideas, as well as was yet another way in which it sought to ensure better output performance in the Eurozone (Ban and Schmidt $n / a)$. 
The ECB was also a key player in using persuasive power through ideas to (re)define what would constitute output legitimacy. Although in the early stages of the crisis, the ECB insisted on the importance of maintaining its 'credibility' through a strict interpretation of its mandate, beginning in 2012, with the arrival of a new President, Mario Draghi, and as the ECB engaged in more robust bond-buying programmes, it switched its legitimizing discourse to a focus on 'stability' (see Drudi et al. 2012). The shift in the discourse from an emphasis on credibility to one focused on stability was intended to help legitimate bond buying while overcoming the resistance of those who retained a narrow reading of the 'no-bailout clause'. Any reinterpretation of the rules was not easy because of very different ideas held initially by members of the ECB board between more pragmatic central bankers willing to take an increasingly expansive interpretation of the rules and more orthodox ones insisting on following the rules as heretofore strictly defined. Inside the ECB, member state representatives to the ECB governing board were engaged behind closed doors in processes of persuasion and contestation. Initially, the more orthodox bankers, mainly from Northern Europe, formed a blocking coalition around Germany, but this changed as more and more Northern European countries rallied around the ECB President. This left the Bundesbank increasingly on its own to espouse the most orthodox positions (Schmidt 2016).

We should also note, in passing, that the ECB also sought to use its coercive power over ideas to push austerity and structural reform as a quid pro quo for its bond-buying - like it (Germany and its Northern European allies) or not (Southern Europe). Its role in the Troika was especially harsh, although arguably no more so than member-state finance ministers in the Eurogroup (as represented by the Commission). And here, one could easily argue that the reforms imposed reflected not just coercive power over ideas (as governments took on the conditionality policies as their own) but coercive power tout court, since they had no alternative, given that exit from the euro was not a viable option (Tsebelis 2015; Schimmelfennig 2015). In these cases, the ECB was clearly not speaking to 'the people' of the countries in trouble but rather to member-state leaders.

Overall, however, member-state leaders in the Council, particularly the ones representing socalled 'debtor countries' in the periphery, along with institutional actors like the ECB and the Commission, have each in their own way largely employed ideational power through ideas to make the case for a reinterpretation of what constitutes the (output) effectiveness of policy outcomes for the people. The result has been a transformation from a strict interpretation of institutionalized ideas about the most effective policy approaches to economic and financial governance in the EMU towards an interpretation more open to allowing for growth and flexibility. The challenge for EU actors, in short, has been how to get beyond the original policies to more workable ones in a context in which formal policy change has been difficult due to institutional- legal constraints and politico-economic divisions. For the Commission and the ECB in particular, this has demanded the exercise of ideational power to convince other EU actors not only that such changes would produce better outcomes but also that the policy processes involved in implementing such changes would be of the highest quality, and thus also meet standards of throughput legitimacy, the issue we turn to next.

Throughput legitimacy and ideational power 
When ideational power is matched with throughput legitimacy, defined as the efficacy, accountability and transparency of the EU's governance processes along with their inclusiveness and openness to consultation with the people, we again find three pathways to legitimacy. In the case of power through ideas, throughput legitimacy involves seeking to persuade actors that procedural rules of accountability, transparency and inclusiveness and openness have been followed appropriately and with efficacy. In the case of power over ideas, throughput legitimacy involves imposing certain conceptions of efficacy, accountability, transparency, inclusiveness and openness while keeping alternatives off the agenda. In the case of power in ideas, throughput legitimacy involves the institutionalization and hegemony of certain approaches to efficacy, accountability, transparency, inclusiveness and openness. Over the course of the euro crisis, political struggles between contending views of what role accountability, transparency and inclusiveness should take in crisis management has often taken center stage. Once again, there is an important institutional background to this story. As already discussed above, the EU naturally lacks the straightforward flow found in national systems from citizen input to procedural throughput to policy performance, and back to citizen input through feedback mechanisms, given the multi-level nature of the system (Schmidt 2013,). As for throughput legitimacy, it has long been one of the central ways in which EU institutional players have sought to counter claims about the poverty of the EU's input legitimacy and to reinforce claims to its output legitimacy (Héritier 1999). This claim has come under severe pressure during the euro crisis.

In the first place, the increase in the Council's intergovernmental decision-making that centralized power in the hands of member-state executives, however necessary at the height of the crisis, not only worked to the detriment of the more 'input legitimate' co-decision making with the European Parliament. It also cut off the 'throughput' legitimacy that comes with greater transparency in decision-making as well as inclusiveness, by closing off decision-making to pluralist processes through the EP or the Commission, which tend to provide access to citizens operating in cross-national as well as national interest groups and social movements. The Council has come in for criticism as a result of its intergovernmental monopoly on decisionmaking, dominated by Germany and other 'creditor' countries, largely because of its incompetence in crisis-management (as the crisis went on and on, unresolved), along with its lack of transparency as well as its perceived bias against 'debtor' countries (e.g., Fabbrini 2013; Matthijs and Blyth 2015; Schmidt 2015). But regardless of the criticism, the dominance of a powerful alliance of creditor countries, headed by Germany, suggests that intergovernmental processes of decision-making benefited from power in ideas, since member-state leaders simply assumed the throughput (as well as input and output) legitimacy of their monopolization of the decision-making process, and were blind to alternatives. Power in ideas was also in play as particularly the Commission and the EP simply went along with the predominance of intergovernmental decision-making, without protest, at least at first.

Given their lack of direct democratic mandate, it comes as little surprise that supranational institutions like the ECB and the Commission have been particularly hard pressed to defend the legitimacy of their throughput processes. As Torres $(2013,290)$ argues, being cut off from input legitimacy (except for what was gained from the initial member state decisions to delegate monetary authority) ensures that "the ECB has a strong interest in finding ways to be perceived, on the one hand, as accountable and transparent (and within a wider EMU cum EU governance system, responsive) and, on the other hand, as acting effectively on behalf of the interest of 
European or Eurozone citizens (output legitimacy)." In the first instance, the ECB defended its relatively restrained response, along with its rejection of the role of Lender of Last Resort, by drawing on the institutionalized power in ideas of its need to maintain credibility cum independence, i.e. that to maintain the bank's credibility for the markets they needed to follow the ECB's mandate of inflation fighting while maintaining its total independence from the political pressures of the member states. When Mario Draghi was appointed head of the ECB in 2011, he reiterated this commitment and the Brussels-Frankfurt mantra in his first press conference, insisting that "continuity, credibility and consistency are of the essence in the way we carry out our jobs" and resisting any suggestion that the ECB could act as lender of last resort (Draghi 2011).

But "the Single Currency did not play by the rules", as Erik Jones (2013) puts it. As a result, the ECB decided to move to a more considered view of how to reinterpret the rules in order to produce effective output, by going from a very strict interpretation of its mandate to an increasingly loose one. This demanded the use of persuasive power through ideas to ensure continued throughput legitimacy. The ECB's reinterpretation of its Charter, in particular following President Draghi's promise to do 'whatever it takes to save the euro' in July 2012, was largely hidden 'in plain view,' as the ECB sought to persuade the public as well as other EU actors that everything that it did was part of its mandate (Schmidt 2016). As such, its discourse switched from claims to maintaining credibility to ensuring 'stability in the medium term', to ensure the euro, as it instituted increasingly non-orthodox bond-buying programs, in particular through the Open Monetary Transactions (OMT) program designed to save Italy and Spain from market attacks in 2012 (but never taken up) all the way to quantitative easing beginning in 2015. While the ECB's persuasive power through ideas can be assessed as very high with regard to the markets in 2012-which stopped their attacks immediately, without the ECB needing to take any further action -it was not nearly as successful with QE, which was much appreciated in Southern Europe but strongly contested by Germans and other Northern Europeans-central bankers, politicians, and 'savers'. Here, the ECB's institutional power to do what it saw as necessary was as much in play as its persuasive power through ideas with regard to the majority of its board.

Notably, moreover, the ECB remained true to the ideas of the Frankfurt-Brussels consensus, and its underlying ordoliberal principles. From the very beginning of the crisis, in a quid pro quo for its bond-buying programs, it pushed the member states to remedy the problems of the euro's governance as well as, to get their own houses in order through structural reforms (Schmidt 2016). The significantly strengthened role of the ECB in crisis management in turn opened the way for increased influence of the EP on Eurozone governance, as seen in the establishing of 'Economic Dialogues', or in the success achieved by the EP in strengthening the SGP through reverse qualified majority voting, which implied the need for a qualified majority of member states to block warnings and sanctions against debt offenders (Torres 2013: 295).

As argued by Schmidt (2015), the EU Commission's democratic legitimacy rests less on its Council and EP-derived input legitimacy than on the quality of its throughput processes of governance. In the Eurozone crisis, however, the Commission seemed to eschew the transparency, openness, and accessibility that characterize its general approach to formulation processes. Moreover, as economic output performance deteriorated, the Commission chose to reinterpret the rules 'by stealth.' At the same time that the Commission more and more frequently granted derogations and exceptions to the rules, DG ECFIN Commissioner Olli Rehn 
insisted over and over again in his communicative discourse that the Commission continued to strictly apply the rules of austerity and structural reform (Schmidt 2016). The disconnect between rhetoric and reality can be explained by the Commission's lack of independence, especially in comparison to the ECB, its concern about legal obligations, and the fact that it was caught between Southern European member states in need of exceptions and Northern European member-states still very much wedded to the 'stability culture' and ordo-liberal ideas (Howarth and Rommerskirchen 2013; Matthijs 2016). By 2015, however, the new Juncker Commission finally acknowledged its flexible application of the rules, and sought to legitimate it in the face of criticism from some Northern European member-states by instituting rules governing flexibility

Finally, contending views about throughput legitimacy have also clashed in debates about the revamped economic and fiscal governance structures of the EMU. Here, again, we see a split between governance mechanisms set up through intergovernmental agreements on one hand, and on the other hand institutions set up within the treaty based institutional setup of EU law (Rittberger 2014). A case in point is the European Stability Mechanism, which follows a very narrow definition of accountability, by charging Eurofinance ministers alone with oversight, and of transparency, on the grounds that information garnered by the markets if the ESM were transparent about their decisions would be deleterious to output performance legitimacy. This contrasts with the Juncker investment fund, set up as the most transparent EU body through maximal access to information, in addition to the most accountable, with multiple forums of accountability, including the EP. As argued by Ban and Schmidt (n/a), the output legitimacy concerns of the ESM regarding lending performance, along with its intergovernmental set-up and relationship to the financial markets, have largely meant that while it has been strong in terms of integrity and accountability to shareholders, it has been quite weak in other aspects of throughput legitimacy, in particular in terms of accountability to EU institutions, transparency, inclusiveness and openness. In contrast, the EFSI has been much stronger in all forms of throughput legitimacy, which results both from its supranational character and its different relation to the markets.

\section{Conclusion}

Legitimacy is a essentially contested concept that political actors are continually trying to claim, maintain or challenge (Rittberger and Schroeder 2016). In the context of the euro crisis this has at least two important implications. First, various forms of power play a decisive role in establishing the standards of legitimacy against which policies and institutions are judged. Weber (1978) famously argued that to turn power into authority demanded a belief in the legitimacy of those wielding power. Such beliefs are importantly also subject to political actors' efforts of manipulation, domination and persuasion, and to understand how legitimacy is established thus requires an acute appreciation of how ideational power plays into the wielding of coercive, institutional or structural forms of power.

Second, this opens the way for an understanding of how in contests for legitimacy, power is not unquestionable, but instead requires continual justification. It also follows from the insight that legitimacy is key for the stability of governance that we cannot a priori determine the primacy of coercive and institutional forms of power and that ideational power somehow plays a 
secondary role. In sum, analysing the trajectory of legitimacy building in the Eurozone crisis should not involve picking one most salient form of power, but rather requires devising an analytical framework that take due account of the dynamic interaction among different dimensions of power.

With this analytical starting point, the paper couples existing accounts of legitimacy in the context of the European Union with insights from the broader discussion of power in politics, producing a matrix of pathways to legitimation that each played a role in the management of the euro crisis. Although it remains well beyond the scope of the paper to offer anything like a full analysis of the trajectory of Eurozone crisis management, the analysis offered ample support for the key claim that ideational power played into processes of legitimation. This was seen both in actors' efforts to bolster the power that followed from their institutional position or resources but also, and importantly, in actors' use of ideational power to challenge existing power relations, basing their claim to increased influence on their legitimacy. In other words, agents could not rely only on material resources or institutional position to legitimize their policies.

Looking ahead, such dynamics of legitimation are likely to play an increasingly important role in international political economy. With the rise of populism and 'post-truth' from the fringes to the core of politics (see Schmidt 2017), power dynamics are bound to be reshaped in ways that put pressure on what use to be strong-holds of professions and experts, in turn potentially opening the way for traditionally less powerful groups to influence what is perceived as just and fair. Finding out what the impact of the rise of populism will be on dynamics of institutional change will require an appreciation of different kinds of legitimacy as they relate to policymakers' capacity to employ discursive strategies that confer legitimacy on the ideas they seek to promote. In conceptualizing the connections between legitimacy and three forms of ideational power, this paper thus seeks to push constructivist analysis towards further engagement with the question of how the ideational power of elites - which remains the main focus of the majority of discursive institutionalist analyses - is connected with the capacity for effective public legitimization, or, in other cases, to keep the struggle for legitimacy among elite peers and out of the public eye. The capacity to control the avenues of legitimization is thus likely to only prove more central in these times of turbulence, which suggests that theorizing legitimacy struggles should be placed among the key scholarly concerns of international political economy.

\section{References}

Apeldoorn, Bastiaan van (2013). 'The European Capitalist Class and the Crisis of its Hegemonic Project', Socialist Register 2014, Pontypool: Merlin

Auel, Katrin and Oliver Höing (2014) "Parliaments in the Euro Crisis: Can the Losers of Integration Still Fight Back?", Journal of Common Market Studies 52 (6): 1184-1193.

Ban, Cornel and Schmidt, Vivien A. (n/a) "Governing Legitimacy in the Eurozone Crisis: Comparing EU Financial Institutional Actors-the European Stability Mechanism and the Juncker Plan." , unpublished manuscript.

Beetham, David (1991) The Legitimation of Power, London: MacMillan 
Beetham, David (2013) "Revisiting Legitimacy, Twenty Years On, pp. 19-36 in Justin Tankebee and Alison Liebling (eds.) Legitimacy and Criminal Justice, Oxford University Press.

Beetham, D. and Lord, C. (1998) Legitimacy and the European Union, London: Longman

Bellamy, Richard (2010) “Democracy without democracy? Can the EU's democratic 'outputs' be separated from the democratic 'inputs' provided by competitive parties and majority rule?", Journal of European Public Policy 17 (1): 2-19.

Bellamy, Richard and Albert Weale (2015) "Political legitimacy and European monetary union: Contracts, constitutionalism and the normative logic of two-level games", Journal of European Public Policy 22 (2): 257-274.

Bickerton, C. (2012) European Integration: From Nation States to Member States, Oxford: Oxford University Press

Blyth, Mark (2007) "Powering, Puzzling, or Persuading? The Mechanisms of Building Instituional Orders”, International Studies Quarterly 51 (4): 761-777.

Blyth, Mark (2013) Austerity: The History of a Dangerous Idea, New York: Oxford University Press.

Braun, Benjamin and Marina Hübner (2018) "Fiscal fault, financial fix? Capital Market Union and the quest for macroeconomic stabilization in the Euro Area", Competition \& Change 22 (2): 117138.

Braun, Benjamin, Daniela Gabor and Marina Hübner (2018) "Governing through financial markets: Towards a critical political economy of Capital Market Union", Competition \& Change 22 (2): 101-116.

van der Brug, Wouter and Claes H. De Vreese (eds.) (2016) (Un)intended Consequences of EU Parliamentary Elections, Oxford University Press.

Carstensen, Martin B. and Vivien A. Schmidt (2016) "Power through, over and in ideas: Conceptualizing ideational power in discursive institutionalism", Journal of European Public Policy, 23 (3): 318-337.

Carstensen, Martin B. and Vivien A. Schmidt (2018) "Power and changing modes of governance in the euro crisis", Governance, forthcoming.

Cerutti, F. (2008) 'Why legitimacy and political identity are connected to each other, especially in the case of the European Union', in F. Cerutti and S. Lucarelli (eds.) The Search for a European Identity, London: Routledge.

Champeau, S., Closa, C., Innerarity, D., Maduro, M. Eds. (2015) The Future of Europe: Democracy, Legitimacy and Justice after the Euro Crisis London: Rowman \& Littlefield

Copelovitch M, Frieden J and Walter S (2016) "The political economy of the euro crisis", Comparative Political Studies 49(7): 811-840.

Cramme, Olaf and Hobolt, Sara B. eds. (2015) Democratic Politics in a European Union under Stress. Oxford: Oxford University Press 
Crum, Ben and Curtin, Deirdre (2015) "The Challenge of Making European Union Executive Power Accountable" in Simon Piattoni (ed.) The European Union: Democratic Principles and Institutional Architectures in Times of Crisis, Oxford: Oxford University Press

Culpepper, P. (2011). Quiet Politics and Business Power: Corporate Control in Europe and Japan. New York: Cambridge University Press.

Culpepper, Pepper (2015) "Structural power and political science in the post-crisis era", Business and Politics 17 (3): 391-409.

Culpepper, Pepper and Raphael Reinke (2014) "Structural Power and Bank Bailouts in the United Kingdom and the United States", Politics \& Society 42 (4): 427-554.

Draghi, Mario (2011) "Introductory statement to the press conference", The European Central Bank, 3. November 2011, retrieved from https://www.ecb.europa.eu/press/pressconf/2011/html/is111103.en.html

Drudi, F., A. Durré and F. P. Mongelli (2012) "The Interplay of Economic Reforms and Monetary Policy: The Case of the Euro Crisis", ECB Working Paper Series, No 1467, September 2012.

Easton, D. (1965) A Systems Analysis of Political Life, New York: Wiley

Engelen, Ewald and Anna Glasmacher (2018) "The waiting game: How securitization became the solution for the growth problem of the Eurozone", Competition \& Change 22 (2): 165-183.

Epstein, Charlotte and Martin Rhodes (2018) "From governance to government: Banking union, capital markets union and the new EU", Competition \& Change 22 (2): 205-224.

Fabbrini, Sergio. (2013). “Intergovernmentalism and its limits: Assessing the European Union's Answer to the Euro Crisis," Comparative Political Studies (46) 9: 1003-1029.

Fawcett, Paul and David Marsh (2014) "Depoliticisation, governance and political participation", Policy \& Politics 42 (2): 171-188.

Flinders, Matthew and Matt Wood (2014) "Depoliticisation, governance and the state", Policy \& Politics 42 (2): 135-149.

Follesdal, A. (2006) 'The Legitimacy Deficits of the European Union', Journal of Political Philosophy 14(4), 441-68

Gilley, B. (2009) The Right to Rule: How States Win and Lose Legitimacy, New York: Columbia University Press.

Haas, Ernst B. (1958) The Uniting of Europe: Political, Social and Economic Forces, 1950-1957, Stanford University Press.

Hall, Peter A. (2016) "The Euro Crisis and the Future of European Integration", pp. 47-67 in The Search for Europe: Contrasting Approaches, Madrid: BBVA

Helgadottir, Oddný (2016) "The Bocconi Boys go to Brussels: Italian Economic Ideas, Professional Networks and European Austerity", Journal of European Public Policy, 23 (3): 392409. 
Héritier, A. (1999) Policy-making and Diversity in Europe: Escape from Deadlock Cambridge: Cambridge University Press

Héritier, A., Moury, C., Magnus, G. Schoeller, K., Meissner, I. (2016) 'The European Parliament as a Driving Force of Constitutionalisation'. Report for the Constitutional Affairs Committee of the European Parliament. PE 536.467

http://www.europarl.europa.eu/committees/en/supporting-analyses-search.html

Hix, S. (2008). What's Wrong with the European Union and how to fix it Cambridge: Polity Press

Hix, S. and Høyland, B. (2013) 'Empowerment of the European Parliament', Annual Review of Political Science Vol. 16, pp.171-89

Hix, S. and B. Hoyland (2015) The Political System of the European Union, 3rd edition, Palgrave MacMillan.

Hooghe, L. and Marks, G. (2009) 'A Postfunctionalist Theory of European Integration: From Permissive Consensus to Constraining Dissensus', British Journal of Political Science 39 (1): 123.

Howarth, D., \& Rommerskirchen, C. (2013). A panacea for all times? The German stability culture as strategic political resource. West European Politics, 36(4), 750-770.

Jones, Erik (2013) "The Collapse of the Brussels-Frankfurt Consensus and the Future of the Euro", In Vivien A. Schmidt and Mark Thatcher (eds.) Resilient Liberalism: European Political Economy Through Boom and Bust. Cambridge: Cambridge University Press

Jones, Erik, Daniel Kelemen and Sophie Meunier (2016) "Failing Forward? The Euro Crisis and the Incomplete Nature of European Integration", Comparative Political Studies 49 (7).

Katz, Richard. S. and Bernhard Wessels (1999) The European Parliament, the National Parliaments, and European Integration, Oxford: Oxford University Press

Kelemen, Daniel (2017) “Europe’s Other Democratic Deficit: National Authoritarianism in Europe's Democratic Union" Government and Opposition, 52 (2): 211-238

Keohane, R. and Hoffmann, S. (1991) The New European Community, Boulder: Westview Press.

Koopmans, R. and Paul Statham (eds.) (2010) The Making of a European Public Sphere: Media Discourse and Political Contention. New York: Cambridge University Press

Kriesi, H., Grande, E. and Lachat, R. (2008) West European Politics in the Age of Globalization Cambridge: Cambridge University Press.

Kriesi, Hanspeter (2014) “The Populist Challenge,” West European Politics vol. 37, no. 2: 379-9

Lindberg, Leon and Sheingold, Stuart (1970) Europe's Would-be Polity: Patterns of Change in the European Community New York: Prentice-Hall

Lukes, S. (1974). Power: A radical view. London: MacMillan. 
Lukes, Steven (1977) "Power and Structure”, in Steven Lukes Essays in Social Theory, London: Macmillan

Lukes, S. (2005). Power, freedom and reason. In S. Lukes (Ed.), Power: A radical view (2nd ed., pp. 60-107). London: Macmillan.

Majone, Giandomenico (1996) Regulating Europe, London: Routledge

Majone, Giandomenico (2001) "Nonmajoritarian Institutions and the Limits of Democratic Governance: A Political Transaction-Approach", Journal of Institutional and Theoretical Economics 157 (1): 57-78.

Majone, G. (1998). 'Europe’s Democratic Deficit', European Law Journal, Vol. 4, No. 1, pp. 5-28. Matthijs, M. (2016) "Powerful rules governing the euro: The perverse logic of German ideas", Journal of European Public Policy 23(3), 375-391.

Matthijs, Matthias (2017a) “Europe After Brexit: A Less Perfect Union”, Foreign Affairs 96 (1): 85-95.

Matthijs, Matthias (2017b) “The Euro's 'Winner-Take-All' Political Economy: Institutional Choices, Policy Drift, and Diverging Patterns of Inequality", Politics \& Society 44 (3): 393-422.

Matthijs, Matthias and Mark Blyth (2015) "Introduction: The Future of the Euro and the Politics of Embedded Currency Areas", in Matthias Matthijs and Mark Blyth (eds.) The Future of the Euro, New York: Oxford University Press

Matthijs, Matthias and Mark Blyth (2017) "When Is It Rational to Learn the Wrong Lessons? Technocratic Authority, Social Learning, and Euro Fragility", Perspectives on Politics, forthcoming, doi:10.1017/S1537592717002171

Matthijs, Matthias and Kathleen R. McNamara (2015) “The Euro Crisis' Theory Effect: Northern Saints, Southern Sinners, and the Demise of the Eurobond", Journal of European Integration 37 (2): 229-245.

Mcevoy, C. (2016) "The Role of Political Efficacy on Public Opinion in the European Union", JCMS: Journal of Common Market Studies 54 (5): 1159-1174

McNamara, Kathleen R. (2015) The Politics of Everyday Europe: Constructing Authority in the European Union, Oxford University Press.

Moravcsik, A. (2002) 'Reassessing Legitimacy in the European Union', Journal of Common Market Studies 40 (4), 603-624.

Pagliari, Stefano and Kevin Young (2016) "The interest ecology of financial regulation: interest group plurality in the design of financial regulatory policies", Socio-Economic Review 14 (2): 309-337.

Pierson, Paul (2004) Politics in Times Princeton: Princeton University Press Reus-Smit, C (2007) "International Crises of Legitimacy" International Politics 44: 157-174. 
Risse, T. (2010) A Community of Europeans? Ithaca: Cornell University Press

Rittberger, Berthold (2014) “Integration without Representation? The European Parliament and the Reforms of Economic Governance in the EU", Journal of Common Market Studies 52 (6): 1174-1183.

Rittberger, Berthold and Philipp Schroeder (2016) “The Legitimacy of Regional Institutions”, in Tanja A. Börzel and Thomas Risse (eds.) The Oxford Handbook of Comparative Regionalism, Oxford: Oxford University Press, p. 579-599.

Salines, Marion, Gabriel Glöckler and Zbigniew Truchiewski (2012) "Existential crisis, incremental response: the eurozone's dual institutional evolution 2007-2011", Journal of European Public Policy 19 (5): 665-681.

Sandholtz, Wayne and Alec Stone Sweet (1998) European Integration and Supranational Governance, Oxford University Press.

Schäfer, David (2016) "A Banking Union of Ideas? The Impact of Ordoliberalism and the Vicious Circle on the Banking Union", Journal of Common Market Studies, 54 (4): 961-980.

Scharpf, F. W. (1970) Demokratietheorie zwischen Utopie und Anpassung. Konstanz: Universitätsverlag

Scharpf, Fritz W. (1999) Governing in Europe, Oxford: Oxford University Press

Scharpf, Fritz W. (2013) "Monetary Union, Fiscal Crisis and the Disabling of Democratic Accountability", in Armin Schäfer and Wolfgang Streeck (eds.) Politics in the Age of Austerity. Cambridge: Polity Press, 108-142.

Scharpf, Fritz W. (2014a) "After the Crash: A Perspective on Multilevel European Democracy", MPIfG Discussion Paper 14/21, Cologne: Max Planck Institute for the Study of Societies.

Scharpf, Fritz W. (2014b) "Political Legitimacy in a Non-Optimal Currency Area", in Olaf Cramme and Sara B. Hobolt (eds.) Democratic Politics in a European Union Under Stress, Oxford University Press.

Scharpf, Fritz W. (2016) "De-Constitutionalization and Majority Rule: A Democratic Vision for Europe”, MPIfG Discussion Paper 16/14, Cologne: Max Planck Institute for the Study of Societies.

Schimmelfennig, F. (2014). "European integration in the euro crisis: The limits of postfunctionalism." Journal of European Integration, 36(3), 321-337.

Schimmelfennig, Frank (2015) "Liberal intergovernmentalism and the euro area crisis", Journal of European Public Policy 22 (2): 177-195.

Schmidt, V. A. (2006) Democracy in Europe Oxford: Oxford University Press

Schmidt, Vivien A. (2008) "Discursive Institutionalism: The Explanatory Power of Ideas and Discourse", Annual Review of Political Science 11: 303-326

Schmidt, Vivien A. (2013) "Democracy and Legitimacy in the European Union Revisited: Input, Output and 'Throughput", Political Studies 61 (1): 2-22 
Schmidt, Vivien A. (2015) “Forgotten Democratic Legitimacy: 'Governing by the Rules' and 'Ruling by the Numbers'", in Matthias Matthijs and Mark Blyth (eds.) The Future of the Euro, Oxford: Oxford University Press.

Schmidt, Vivien A. (2016) "Reinterpreting the Rules 'by Stealth' in Times of Crisis: The European Central Bank and the European Commission." West European Politics Vol. 39, no. 5: $1032-1052$

Schmidt, Vivien A. (2017) "Britain-Out and Trump-In: A Discursive Institutionalist Analysis of the British Referendum on the EU and the US Presidential Election," Review of International Political Economy vol 24, no. 2 (2017): 248-269

Schmidt, Vivien A. and Thatcher, Mark (2013) Resilient Liberalism in Europe's Political Economy Cambridge: Cambridge University Press

Schmitt, Hermann and Jacques Thomassen (1999) Political Representation and Legitimacy in the European Union, Oxford University Press.

Seabrooke, Leonard (2006) The Social Sources of Financial Power: Domestic Legitimacy and International Financial Orders, Ithaca: Cornell University Press.

Seabrooke, Leonard (2014) "Epistemic arbitrage: Transnational professional knowledge in action," Journal of Professions and Organization 1 (1): 49-64.

Seabrooke, Leonard and Eleni Tsingou (2018) “Europe's fast- and slow-burning crises”, Journal of European Public Policy, DOI: 10.1080/13501763.2018.1446456

Sternberg, Claudia S. (2013) The Struggle for EU Legitimacy: Public Contestation, 1950-2005, Palgrave MacMillan.

Sternberg, Claudia S. (2015) "Political legitimacy between democracy and effectiveness: tradeoffs, interdependencies, and discursive constructions by the EU institutions", European Political Science Review 7 (4): 615-638.

Sternberg, Claudia S., Kira Gartzou-Katsouyanni and Kalypso Nicholaidis (2018) The GrecoGerman Affair in the Euro Crisis: Mutual Recognition Lost?, London: Palgrave MacMillan.

Streeck, Wolfgang (2014) Buying Time: The Delayed Crisis of Democratic Capitalism, London: Verso.

Torres, Francisco (2006) "On the efficiency-legitimacy trade-off in EMU”, pp. 31-48 in Francisco Torres, Amy Verdun and Hans Zimmerman (eds.) EMU Rules: the Political and Economic Consequences of European Monetary Integration, Baden-Baden: Nomos.

Torres, Francisco (2013) “The EMU's Legitimacy and the ECB as a Strategic Political Player in the Crisis Context", Journal of European Integration 35 (3): 287-300.

Tsebelis, G. (2015) “Lessons from the Greek crisis”, Journal of European Public Policy, 23(1), 25 41. 
Tsoukalis, Loukas (2016) In Defence of Europe: Can the European Project be Saved? Oxford: Oxford University Press

Verdun, Amy (2015) "A historical institutionalist explanation of the EU's responses to the euro area financial crisis”, Journal of European Public Policy 22 (2): 219-237.

Weber, Max (1978) Economy and Society, edited by Guenther Roth and Claus Wittich, Berkeley: University of California Press

Weiler, J. H. H. (1995) “Does Europe Need a Constitution? Demos, Telos and the German Maastricht Decision", European Law Journal 1 (3): 219-258.

Wessels, W. and Rozenberg, O. (2013) 'Democratic Control in the Member States of the European Council and the Euro Zone Summits'. Study PE 474.392. Available at: «http://www.europarl.europa.eu/RegData/etudes/etudes/join/2013/474392/IPOLAFCO_ET( 2013)474392_EN.pdf».

Widmaier, Wesley, Mark Blyth and Leonard Seabrooke (2007) "Exogenous Shocks or Endogenous Constructions? The Meanings of Wars and Crises", International Studies Quarterly 51 (4): 747-759.

Woll, Cornelia (2014) The Power of Inaction: Bank Bailouts in Comparison, Ithaca: Cornell University Press 